\title{
Investigation of the Lexical-Semantic Field of "Joy"/ "Shod-Xurramlik" in English and Uzbek Languages
}

\author{
Maxammatjon Arabovich Abduvaliev ${ }^{1}$; Valijon Abduvahobovich Vositovi'; Abdurashid \\ Isaqovich Ismoilov²; Bahromjon Abduraimovich Saidov²; Ahmadbek Sohibjon Uglj \\ Bozorbekov $^{2}$ \\ ${ }^{1} \mathrm{PhD}$, Associate Professor, Andijan State University, Uzbekistan \\ ${ }^{2}$ Teacher, Andijan State University, Uzbekistan \\ http://dx.doi.org/10.18415/ijmmu.v8i8.2975
}

\begin{abstract}
The article deals with structural-semantic, stylistic-functional,linguopragmatic and linguocultural aspects of the constituents of the lexical-semantic field of "joy"/ "shod-xurramlik" in English and Uzbek.
\end{abstract}

Keywords: Lexical-Semantic Field; Field Constituents; Dominant; Centre; Periphery; Archiseme; Deep Structure; Surface Structure; Linguopragmatic Features; Linguocultural Aspect

\section{Introduction}

Field studies have already become one of the affective methods in the scientific understanding dialectical relations of the world, objective reality, thought and language. Today we have different field paradigms based on semantic relations and language levels: paradigmatic field (Trier, Kosirio, Lounsterry), syntactic field (Portzig, Weisgerber, Filicheva), grammatic fields (Admoni), grammaticlexical field (Guliga, Shendels), functional semantic field (Bondarko), conceptual field, semantic field (Buslayev, Potebnya, Peshkovskiy), conceptual field (nominative field of the concept) (Yusupov 2010, Babushkin 2018) etc.

Despite achievements in the general field theory a number of issues connected with field theory and practice are still remaining disputable and unsolved. To them belong, for example, the lack of the universal definition of the linguistic field, conceptual and semantic fields as well; absence of the principles or criteria of determining constituent members and their place within the field, systematic (paradigmatic, syntagmatic) relations of the constituents, linguopragmatic, linguocultural and functional aspects of the language and speech means expressing certain semantics ("joy"/ "shod-xurramlik" in our case) etc.

By lexic-semantic field of "joy"/“shod-xurramlik" we understand the system of language and speech units formed on the basis of certain morphological and syntactic models, united around the invariant archiseme of "joy"/"shod-xurramlik", occupying close and distant positions regarding to the chief meaning, monosemantic and polysemantic, syntagmatic, paradigmatic, symmetric and asymmetric relations with one another, active and inactive, stylistically coloured and neutral. 


\section{Materials and Methods}

Our empiric studies showed that the linguistic expressive means of the semantics of "joy" in English and Uzbek can be: simple words: joy, happy, glad, cheer, to cheer, (V) merry, smile, enjoy, quvonch, sevinch, quvnoq, mamnun, xursand, shod, zavq; derivative words: joyous, joyful, happiness, happily, gaily, pleased, enjoyment; compound words: joy-ride, happy-going, xurram, xushxabar, vaqti chog', kongil oro, zavqbaxsh; word combinations: to make mercy, to have fun, to enjoy oneself, to be glad, to like happily, to grow merry, to give pleasure, to become gay, a gladness of life; xursand bo'lmoq, mazza qilmoq, kayfiyati chog' bo'lmoq, jon deb o'yinga tushmoq; phraseological units: to be in pink, to be in the seventh heaven, as gay as a lark; boshi osmonga yetmoq, terisiga sig'may ketmoq, do'ppisini osmonga otmoq; Paremies: No pleasure without pain; He who pleased everybody died before he was born; Baxt kulgu bor uyga kirar; Oyni o'n beshi qorong'u bo'lsa o'n beshi yorug'. Sentences: I am glad today; Holiday cheer lasted a long time; He gladly received my gift; Sizni ko'rganimdan xursandman; Quvnoq qoshiqlarni tinglang va zavqlaning; Two or more semantically connected sentences (text): The player kicked the ball into the goal and opened the score. The fans started jumping and playing the drums and horns; To'y boshlandi, quvnoq qo'shiqlar davradagilarni raqsga chorladi. Besides the above mentioned verbal means there exist nonverbal means smiling, crying (tears) different gestures and movements of the parts of the head and body that show joy (shod-xurramlik) in the compared languages.

The next step of the investigation is the determination of the place of the expressive linguistic means in the lexical-semantic field of "joy"/"shod-xurramlik". The principles proposed by E.V.Guliga and E.I.Shendels $(1969,182)$ lie on the basis of the analysis. Specialized and less specialized nature of the units for the expression of "joy/shod xurramlik" (with pure and mixed meanings) frequency of the units in different speech situations are taken into consideration. Works of prominent English and Uzbek writers, explanatory dictionaries served as the sources of the materials. Statistic and componential analyses showed the following results:

\begin{tabular}{|l|l|l|l|l|}
\hline \multirow{2}{*}{ Language Units } & \multicolumn{2}{|l|}{ In English } & In Uzbek \\
\cline { 2 - 5 } & Number & $\%$ & Number & $\%$ \\
\hline Verbs & 240 & 32.56 & 304 & 34.78 \\
Verbal phrases & 186 & 25.23 & 223 & 25.5 \\
Phraselogical Units & 5 & 0.67 & 3 & 0.43 \\
Nouns & 138 & 18.72 & 127 & 14.53 \\
Adjectives & 107 & 14.5 & 118 & 13.5 \\
Adverbs & 21 & 2.8 & 14 & 1.6 \\
Paremies & 4 & 0.54 & 3 & 0.34 \\
Sentences & 17 & 2.3 & 20 & 2.3 \\
Word combinations & 15 & 2.03 & 56 & 6.4 \\
Texts & 3 & 0.41 & 6 & 0.68 \\
\hline Total & 737 & $100 \%$ & 874 & $100 \%$ \\
\hline
\end{tabular}




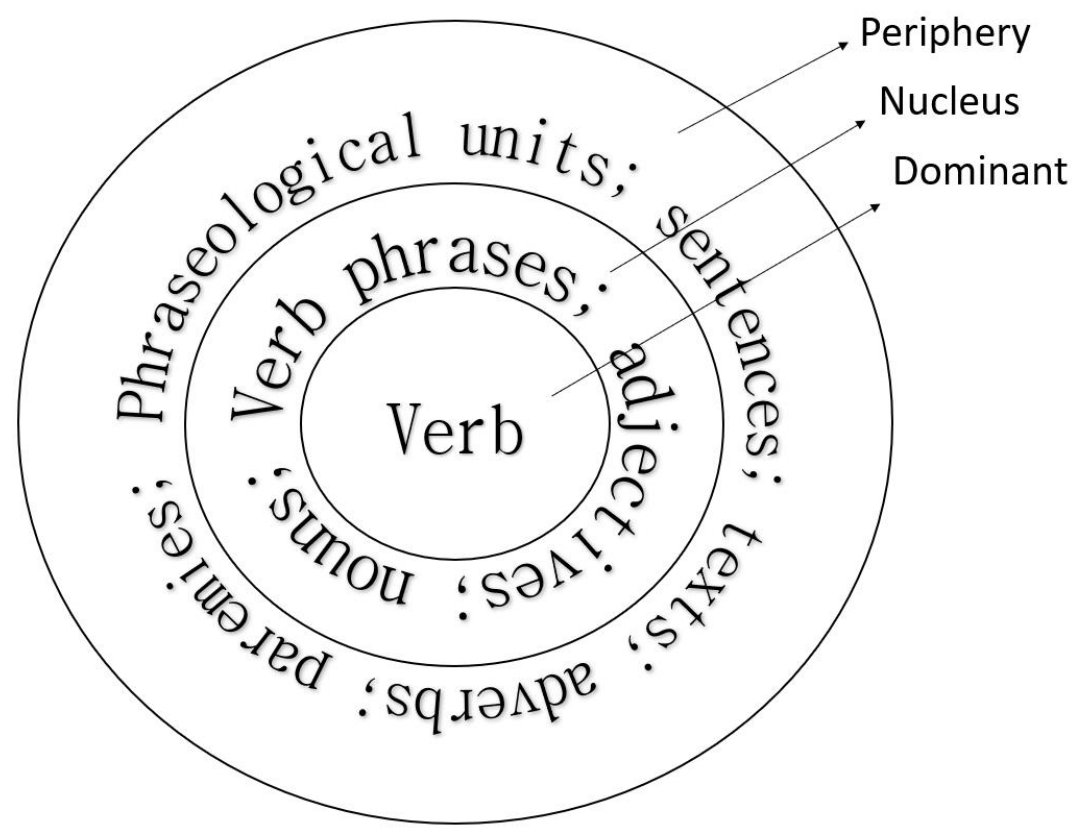

Semantic, functional and statistical analyses showed that the language units make up the field on the basis of the archiseme "joy/shod xurramlik", each means has different (close and distance) semantic relations with the archiseme, different functional loads and occurrence in speech. According to the statistical analysis the verbs that express action and state are dominant in the expression of joy in English and Uzbek. Nouns, verb phrases, adjectives occupy the central part, phraseological units, sentences, paremies and adverbs occupy periphery zone of the field. So, the semantic field of "joy/ shodxurramlik" can be demonstrated in the following way:

The chief meanings of "joy/shod-xurramlik" according to WTNID $(1993,1222)$ is the emotion excited by the acquisition or expectation of good: pleasurable feelings or emotion caused by well-being, success or good fortune or by the prospect of processing what one loves or desires: Gladness, delight.

So, the field of "joy/shod-xurramlik" belongs to the semantic field, expressing the spiritual world of the human being.

Our empiric contrastive studies let us discover that the constituents of the field have similar and specific semantic, structural and functional features. The noun joy, for instance, possesses 8 integral semantic parts while the verb to joy- 7 integral semes, cheer - 7, gay (adj)-8, merriment-3, amuse (v)-6. Derivative affixes (-less, -ful, -ly, -ness) form adjective, noun and adverb words the basic models of which can be $\mathrm{N}, \mathrm{V}, \mathrm{N}+\mathrm{suf}=\mathrm{Adj}, \mathrm{N}+\mathrm{suf}+\mathrm{suf}=\mathrm{Adverb}, \mathrm{N}+\mathrm{suf}+\mathrm{suf}=\mathrm{Noun}$. The noun joy forms semantic relation with the nouns as gladness, delight, enjoyment, gaiety, jubilation, merriment and pleasure. But it is synonymous with bloss in the meaning of only a state of happiness or felicity. The synonyms of the verb to joy are to delight, to gladden, to enjoy, to rejoice and to exult. But these words differ in the degree of intensity of the meanings and functions. The meaning 'to enjoy' of to joy is archaic. It is inactive and rarely used nowadays.

In this connection it is desirable to study syntagmatic (combinability) peculiarities of joy with other lexemes that form various semantics. The noun joy house (slang) means brothel, joy-juice-alcoholic liquor, joy-pop (verb) - to use drugs only occasionally. The opposite of joy (n) is sadness, which has got two integral semes: the quality or state of being sad; as a mood or an appearance of being sad: something powerful, gloomy or depressing: She talked about death as she spoke of the sadness's of nature (Willar Cather). 


\section{Results and Discussions}

Synonym words with the semantics of joy may differ in the expression of this or that seme. We demonstrate it in the following table (in the example of happiness and its synonyms):

\begin{tabular}{|l|l|l|l|}
\hline $\mathbf{N}$ & Synonyms & Similar semes & Differentiating semes \\
\hline 1 & Happiness & $\begin{array}{l}\text { It denotes enjoyment of or } \\
\text { pleasurable satisfaction in well-being } \\
\text { sincerity or fulfillment of wishes }\end{array}$ & - \\
\hline 2 & Fecility & $\begin{array}{l}\text { It denotes a higher, more lasting } \\
\text { happiness }\end{array}$ & $\begin{array}{l}\text { More perfect happiness, more } \\
\text { booking the process of } \\
\text { prospering, long term }\end{array}$ \\
\hline 3 & Beatitude & The quality or state of being blessed & The highest happiness \\
\hline 4 & Blessedness & $\begin{array}{l}\text { It suggests the deep joy of peer } \\
\text { affection or of acceptance }\end{array}$ & By God \\
\hline 5 & Bliss & $\begin{array}{l}\text { A state of complete or ecstatic } \\
\text { happiness }\end{array}$ & Joy of saved souls \\
\hline
\end{tabular}

In this connection it is worth pointing out the fact that the adjective happy may acquire the seme feeling of well-being as a result of drink in definite speech contexts: He came home a bit happy (U uyga biroz kayfi chog' keldi). It is homonymous with the verb to happy (dialectal word, which is rarely used today): Successful marriage happied the couple. The adjective happy in combination with other words produces mainly nouns, sometimes adjectives with a variety of meanings: happy dust means cocaine or heroin, happy family (noun, Australian) means an Australian tabbler of sociable habits, especially groy around tabbler, hunting ground means American-Indian paradise conceived as a region of which souls of warriors and hunters pass after death for the purpose of spending a happy life after hunting and feasting. The following compounds explicitely express joy: merry-andrew (n) one that clowns publicity, merry-goround (n) a circular platform having seats in the form of horses or other animals and relating around a fixing center, found at amusement parks. Merry man is archaic which means a jester. Merry-meeting is also archaic that means a festive gathering, merry night (British dialectal noun). The present word stock of the Uzbek language possesses a great number of simple structured words, derivative, compound and composite words that function as the expressive means of the semantics of "joy"/"shod-xurramlik". Like English lexemes, they also express different degrees of joy.

The derivative noun "shodlik" is the equivalent of the English noun joy. It is close in meaning with quvonch, sevinch, shod-xurramlik, xursandlik (Butayev, 2013, 394).

The word "shod" is an adjective which means xursand, quvonch, xushchaqchaq, mamnun, quvonchga to'la, ko'ngli shod. It becomes a verb when it combines with verbs bo'lmoq, ermoq, and qilmoq: Ona og'lidan xat olibdi. Ona o'zida yo'q shod ekan. Verb phrases shod bo'lmoq, xursand bo'lmoq and the verbs shodlanmoq, sevinmoq, quvonmoq are synonym units.

The adjective shodiyona means a happened or happening gayety or festivity: Uydan shodiyona qichqiriqlar ko 'tarildi. The noun shodiyona is rarely used in Uzbek, the meaning of which is gift given to a man who brings a good news. The basic models of the unit with shodlik are Adj+suf=N; Adj+bo'lmoq $($ ermoq $)=\mathrm{V}$.

The noun quvonch means quvonish his tuyg'usi, xursandlik: Boltaboy otaning quvonchidan Shirmonxon ham bexad shod edi (S. Zunnunova, Olov) 
The word combination with "quvonch" (quvonchi ichiga sig'maydi, quvonchi diliga sig'maydi) means a higher degree of joy (juda xursand (very happy), g'oyat shod (extremely joyful (cheerful, gay): "Birov yor-yor o'qib, tag'in bittasining quvonchi ichiga sig'may, xoxolab dunyoni buzadi"(A. Qodiriy, "O’tgan kunlar")

The word quvonchiq is a dialectal word (adjective). It means: kishiga shodlik, quvonch bag'ishlaydigan, ko'nglini ko'taradigan, xursand qiladigan eng aziz kimsa, narsa: Tohirjon mening ovunchog'im, otasining quvonchig'i bo'lib qoldi. (M. Jo'ra. Iztirob). The verb quvonchiq means xursand bo'lmoq (to be glad-happy): Ota-onam har bir muvaffaqiyatimdan quvonardi. The verb quvontirmoq (to cause to have fun) means, kimnidir quvonishiga sabab bo'lmoq: Uning g'alabasi millatni, xalqni quvontirdi. And the verb "quvnamoq" means xursand, shod kayfiyatda bo'lmoq (to be in a gay, good mood). Besh o'rtoq rossa quvnadik (We, five friends enjoyed ourselves very much).

The equivalent of the English word happy-xursand (means mamnun, qanoatlangan, shod, quvnoq (to be glad-happy), to be satisfied, joyful, merry): Hayotdan juda mamnun, kayfiyati juda yaxshi, shod-xurram, xushchaqchaq: Ozod yoshlarning ruhlari tetik va o'zlari xursand edilar. (N. Fozilov. Diydor)

The noun xursand, it is a name of a man or woman, is homonymous with xursand. Compare the following example: Men Xursandman $\rightarrow$ Men xursandman. The first sentence is the answer to the question Who are you? and the second - to the question: Are you happy? or Who is happy? The noun xursandchilik, which is made of $A d j+s u f+s u f=N$ means vaqtni xursand, shod, o'yin -kulgu bilan o'tkazish. Vaqtichog'lik to have a good time, to spend time gayly, merry making: Xursandchiligimiz ichimizga sig'mayapti.

The adjective xush means yoqimli, yaxshi, quvnoq. It can express different meanings in combination with different words: Ko'ngli xush, xush kelmoq, xush ko'rmoq, xush qolmoq, xushi yo' $q$ etc: Men asalli choyni xush ko'raman. (I like tea with honey). Xush kelibsizlar! (You are welcome!) But the construction xush qoling is used while parting. It is said by the speaker who is leaving someone. The construction xushi yo'q means "yoqtirmaslik" (I do not like (want) black tea)

It is quite different with xushi kelmoq, which means kayfiyati yaxshi bo'Imoq: Xushi kelganda undan quvnoq odam yo'q (when he is in a good mood, he is the happiest man in the world). The combination xushiga kelsa is homonymous with xushiga kelmoq. (to come to conscious). Xushiga kelsa means xohlasa, yoqtirsa. If he wants he comes, if he does not he won't.

The phrase baxt qushi boshiga qo'nmoq means lucky moments have come, happy day have come to him. But in the sense omadi kelmoq, baxti kulmoq, ishi o'ngidan kelmoq, baxti kelmoq, baxti yorishmoq are the synonyms of this phrase.

The lexeme omad, as an expressive means of joy means ishining o'ngidan kelishi, ilgari bosishi, baxt, tole. Har yigitga bir omad (Maqol)

The word combination omadi ketmoq is the opposite of omadi kelmoq. (ishi o'ngidan kelmaslik, ishi orqaga ketmoq, baxt yo'li to'silib qolmoq) The form of omad joins with -li: Dunyoda omadli odamlar $k o ' p$ (There are so many lucky people in the world). The basic model for both of them can be $\mathrm{N}+\mathrm{suf}=\mathrm{Adj}$. The word xuzur means yuqori darajadagi qanoat, qoniqish hissi, kishi vujudi, a'zolarining ayrim holati, rohat (high degree satisfaction, of some parts of body (pleasure): Dehqonchilikning azobi ham bor, huzuri ham bor (Agriculture has both painful and pleasant sides. It often comes with such words as bag'ishlamoq, bor bo'lmoq, qilmoq (to get pleasure, to feel the state of enjoyment). Its adverb form is formed with the help of qilib: Huzur qilib nafas olmoq (to breathe with pleasure), suvni huzur qilib ichmoq (to drink water with pleasure), huzur qilib kulmoq (to laugh with pleasure). The compound adjective huzurbaxsh is made of huzur and baxsh: $\mathrm{N}+\mathrm{V}=\mathrm{Adj}$. It means huzur bag'ishlovchi or xuzur bag'ishlaydigan. Huzurbaxsh navolar har bir joyda yangramoqda. The verb huzurlanmoq is rarely used in Uzbek. Its synonyms huzur qilmoq (to get pleasure) is comparatively often used in communication: Bo'layotgan ishlardan Saida xuzurlanadi, tabassum qildi. The verb rohatlanmoq and the phrase mazza 
qilmoq are also synonyms of the verb huzurlanmoq. Accordingly they are interchangeable: Kuydan huzurlandim $=$ Kuydan rohatlandim $=$ Kuydan mazza qildim.

The compound noun rohat-farog'at means tinch va farovon hayot (peaceful and a-well-to-do life), huzur-xalovat: $U$ rohat farog'atda yashadi. The noun rohat is the homonym of rohat, which means an Uzbek melody. The same refers to the homonymous adjective rohatbadan and the noun rohatbadan.

The verb kulmoq expresses one's happiness and joy with various movements of eyes and lips. The verb, in combination with other lexemes, can express various degrees of laughing: xoholab kulmoq, qahqaha urib kulmoq, muloyim kulmoq, miyig'ida kulmoq: Uning qo'pol hazilidan u miyig'ida kulib $q o^{\prime} y d i$. The next meaning of kulmoq can be masharalamoq, mazax qilmoq, (to ridicule, make fun). So in this case kulish-laugh (laughing) does not express joy or happiness but making fun: Men bu ishlarni qilmayman. Odamlar orqamdan gapirishadi, kulishadi (Oybek). Study of the gestures of the expressive means of joy is also important not only for the theory but for the theory of foreign language learning and translatology.

Our empiric observations practice let us come to the conclusion that the main bulk of lexemes expressing semantics of "joy/shod xurramlik" are charasteric to belles-lettres style which includes units belonging to literary (joy, delight, full of cheerfulness, exhilaration, hilarity, happiness, felicity (archaic), bliss (archaic) rejoice, exult, jubilate, jubilation, cheerful) shod, shodlik, quvonch, sevinch, quvonchi ichiga sig'maydi, tabassum, baxt iqbol, baxti kulmoq, omad qushi boshiga qo'nmoq, mamnun, xurram, xush ko'rmoq, zavqlanmoq, vaqti xushlik, xuzurini ko'rmoq, xuzurbaxsh, rohat, rohatbaxsh, quvonchdan sakramoq, tantana:

Colloquial (merry nights) (dialectal word), joy, stik, merry andrew, joy-juice, cheers, joy-pop, joy-popper, buff (dial), gay dog, gay science (poetry), gay (dial), to happy, to be at the top of ladder. (do'ppisini osmonga otmoq, terisiga sig'maslik, boshi osmonga yetmoq, suyuntirmoq, iljaymoq, og'zi qulog'iga yetmoq, o'yin-kulgi, bir qop semirmoq) neutral (to please, glad, to gladden, happy, satisfied, pleased, cheerleader, to make glad, to cause to be happy, merry, xursand, xursand bo'lmoq, kulmoq, quvnagani kelmoq, xursandligidan dovdirab qolmoq, mazza qilmoq, jilmaymoq, bayram, layers).

The above mentioned means except colloquial ones are also characteristic to newspaper and publicistic styles. It is interesting to point out the fact that some of these lexemes can have expressive and emotional colouring. We shall try to distinguish functions, emotive meanings in the semantic structure of the language units expressing "joy"/"shod-xurramlik"and those units which acquire the meaning in the context, I. R. Galperin writes: "Interjections are words we use when we express our feelings strongly and which may be said to exist in language as conventional symbols of human emotions" (Galperin 1977, 154)

The noun joy can be used interjectionally as an exclamation of delight, especially in the phrase of joy in English. Some units, with joy semantics may possess the status of interjections: Joy! Sadness! (They never leave each other) Quvonch! Shodlik! Qayg'u! Doim ular yonma-yon.

Words with the semantics of joy are often accompanied by attribute words that add a feature to the word, that is unexpected for the reader and strikes him: a heart burning smile (yurakni yondiradigan kulgu), happy dust (kokain, geroin), happy hunting ground (Shimoliy Amerika hindulari, jannat), a laughing frog (Yevropa baqasi), a laughing goose (old tomoni oq g'oz), the shadow of a smile,merry hours (quvnoq tarona, mamnun ko'ngillar, orombaxsh, kulgi.)

Meaning intensifiers, in the function of an adjective mostly, with certain lexemes, meaning of which are opposite, make up the so called oxymoron (adjective+noun) in the compared languages: deadly happy (extremely, excessively happy), a sad smile (xafagg'an kulgu, o'lguday xursand, zavqli tashvishlar) etc. Simile is not a comparison. When we use simile as a stylistic device we characterize one object or person by bringing it into contact with another object belonging to an entirely different group of 
things: She was gay like the shining sun in the sky. Uning ko 'zlari kunning yoritgan oydek kulib turardi. Qizning tabassumi roxatijon buloq suvidek musaffo edi.

\section{Conclusion}

Merry songs and music were as loud as speaking trumpets. Concluding the work we would like to point out the fact that contrastive study the constituents of the field of "joy/shod-xurramlik", their structural semantic, functional, pragmatic and lingua-cultural pragmatic features should be the object of special linguistic investigations.

\section{References}

Annotated dictionary of the Uzbek language. - T., Uzbekistan Publishing House, 2020.

Butayev Sh. English-Uzbek, Uzbek-English dictionary - T., Teacher, 2013.

Cottrell Laura. Joy and happiness: a simultaneous and evolutionary concept analysis. Journal of Advanced Nursing, 72 (7), 1506-15172016, John Willey.

Galparin I.R Stylistics - M., Higher school, 1977.

Gulyga E.V., Shendels E.I. Grammatical and lexical fields in modern German. 1969.

Kunin A.V. Anglo-Russian phraseological dictionary. - M., Soviet encyclopedia, 1967.

Rasuljanovna, I. N. (2019). Lacunas Occurance In Semantic Fields Of Chinese And Uzbek Languages. International Journal of Scientific \& Technology Research, 8(11), 1998-2001.

Safarov Sh. Cognitive linguistics. - Jizzax: Sangzor, 2006.

Sobirov A.Sh. Study of the lexical level of the Uzbek language on the basis of the principle of systems. T., Spirituality, 2004.

Webster's Third New International Dictionary. Könemann, 1993.

Yusupov O'.Q. On the terms of concept and lingoculturema: Current problems of comparative, comparative, typological and general linguistics. Materials of the Republican scientific-practical conference, - Andijan, 2010.

\section{Copyrights}

Copyright for this article is retained by the author(s), with first publication rights granted to the journal.

This is an open-access article distributed under the terms and conditions of the Creative Commons Attribution license (http://creativecommons.org/licenses/by/4.0/). 